\author{
Vasilev Presiyan, PhD Student \\ D.A. Tsenov Academy of Economics, \\ Department of Control and Analysis of Economic Activities
}

\title{
Comparative characteristics of economic crime in Russia and Bulgaria
}

\author{
(Submitted by Ph.D. Vygivska I.M.)
}

\begin{abstract}
The development of economies and legal systems resulted in proliferation of many new types of crime, which are much more difficult to detect and require expertise in various fields. This research on economic crime in Bulgaria and Russia aims to identify the competencies and skills are required from the authorities responsible for prevention and detection of such criminal offences. It also defines and reviews the main methods used to detect fraud and other types of economic crime, outlines the most common types of such crime and analyses the similarities and differences of the concept of «crime» as well as the size and relative share of the related financial damage in both countries.

Keywords: economic crimes; frauds; detection; control.
\end{abstract}

Introduction. Despite some differences in their economic development, Bulgaria and Russia are very similar in terms of social and living conditions, historical past and cultural values. This is why this paper aims to investigate the similarities and differences in the definition and the typology of crime in the two countries and thus to determine whether and to what extent they have developed their capacity and expertise to combat criminal offenses.

Aim and objectives. The aim of this paper is to define the most common types of economic crime and their dynamics in Bulgaria and Russia. This aim is to be accomplished by performing the following tasks:

- to define the term «crime» and the common and diverging characteristics of this term in both countries;

- to trace the dynamics of the various types of economic crime in Bulgaria and Russia;

- to define the means and techniques used for prevention and detection of economic crime;

- to analyse the size and relative share of the related financial damage.

Methods. The findings and conclusions were drawn using common scientific methods, such as induction, deduction, analysis of the types of economic crime, comparison, dialectical method, and synthesis.

In Bulgaria, the term «crime» is defined as an act (action or inaction) dangerous to society, which has been culpably committed and which has been declared punishable by law. An act which, although formally containing the elements of crime provided by law, because of its insignificance is not dangerous to society or its danger to society is obviously insignificant is not considered criminal [1]. This definition reveals the following characteristics of a criminal act:

- in order to be classified as a crime, the act (or inaction) must be dangerous to society, i.e. to threaten or harm the person, the rights of the citizens, the property, the legal order in the country or other interests, protected by the legal system;

- in order to be classified as a crime, the act must be culpably committed (intentional or committed through negligence). Culpability is the mental attitude of the perpetrator to the act, which is harmful to society, and its consequences. It is one of the four characteristics of a crime. Without culpability, there is no crime and, therefore, no liability. [2, p. 37];

- penal liability, i.e. liability to punishment for committing a criminal act;

- illegality, i.e. the breach of any provision of the penal code.

The Criminal Code of the Russian Federation defines crime as a socially dangerous act, committed with guilt and prohibited by the Code under threat of punishment [3] The difference in this case is that a criminal act according to Russia's legislation has five characteristics (while Bulgaria's legislation provides four), which are:

- action (or inaction) - an act or behaviour (or lack thereof) that is intentional and voluntary. Such an act can be both a physical deed and a psychological one, such as a sign, a gesture, a word, etc.;

- social danger - the act must be harmful or threatening to a person, society, state, or other interests;

- illegality, i.e. the breach of any provision of the penal code. However, some first-time offences may not be considered criminal;

- culpability (guilt) - a person who has committed a socially dangerous act deliberately or carelessly and is aware of his actions or inactions is deemed guilty of a crime;

- penal liability, i.e. liability to punishment for committing a criminal act.

The analysis of the two definitions shows that the main characteristics of a criminal act are the same in Bulgaria and in Russia, i.e. its culpability (guilt) for committing a criminal act (or inaction), penal liability, social danger (harmful effect) and illegality. The two legislations differ in terms of the action, which is included as a characteristic criminal acts in Russia. 
Bulgaria's Criminal Code provides the following types of a crime:

- crimes against the Republic;

- crimes against a person;

- crimes against the rights of citizens;

- crimes against marriage, the family and youth;

- crimes against property;

- crimes against the financial, tax and insurance systems.

These types of crimes and the penalties related thereof are provided for in special sections of the Code. Russia's Criminal Code specifies the following types of a crime:

- crimes against a person;

- crimes in the sphere of economics;

- crimes against public security and public order;

- crimes against state power;

- crimes against the peace and security of mankind.

Unlike the Bulgarian Code, Russia's Code has a special section for economic crime, which is categorized into crimes against property (including fraud, theft, misappropriation, extortion), economic offenses and crimes against the interests of businesses and other organizations. [4] Although not categorized as economic crimes, crimes against the financial, tax and social security systems, as well as crimes against property might also be considered as such in Bulgaria since they include theft, fraud, money laundering, misuse of funds, concealment of mandatory social security contributions, which directly or indirectly have a negative impact on the economy. The next step in our survey is to trace the dynamics of an economic crime in the two countries.

The PricewaterhouseCoopers's (PwC) 2018 Global Economic Crime and Fraud Survey shows that, since the 2016 survey, the global level of economic crimes decreased from 38 to $31 \%$ [5, p. 4]. Nevertheless, in Russia the trend is reverse i.e. in 2018, the level of economic crimes was significantly higher compared to the previous period (in 2016, $48 \%$ of the respondents were the target of one or more economic crimes, while in 2018 the relative share of such people was 66\%.) [6, p. 5]. The the dynamics of economic crimes for the period 2009-2018 is shown in Figure 1 below.

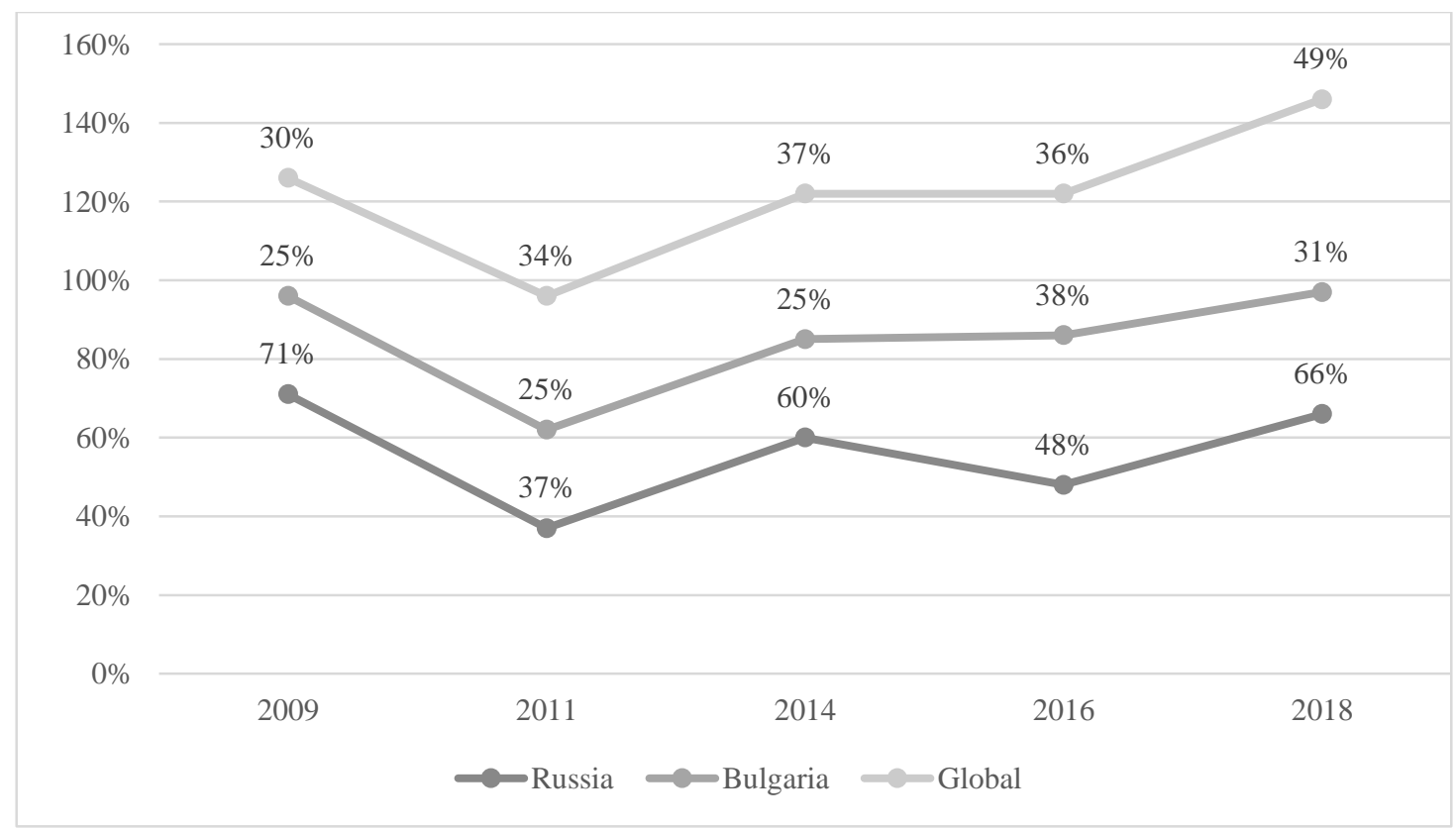

Source: PwC's 2018 Global Economic Crime and Fraud Survey

Figure 1. Dynamics of economic crime in the period 2009-2018 (global, Russia, and Bulgaria)

The figure shows that the level of this type of crime in Bulgaria was significantly lower than the global level, and much below the levels in Russia throughout the entire period. In Bulgaria, the level was close to the global one only in 2016, although the increase of only two percent (to $38 \%$ ) was not significant. The increase was due to various reasons, such as appropriate internal controls, risk management, or investment of resources to improve an organization's security as well as better staff motivation, engagement of employees in a manner that is consistent with the objectives of the organization, appropriate «tone at the top», etc. In Russia, the level was lower (37\%) only in 2011, and higher throughout the rest of the period with a peak of $71 \%$ (twice higher than the global average) in 2009. So high levels are alarming because they may indicate unsuccessful and incompetent 
management of the organization concerned. They may also be due to poor regulation or misinterpretation of the relevant regulations. Another reason may be the improvement of perpetrators of criminal acts, i.e. the use of advanced techniques, approaches, and tools.

The above data clearly shows a tendency of increase in the number of economic crimes in Russia and a reverse trend in Bulgaria. Our next step is to analyse the types of an economic crime:

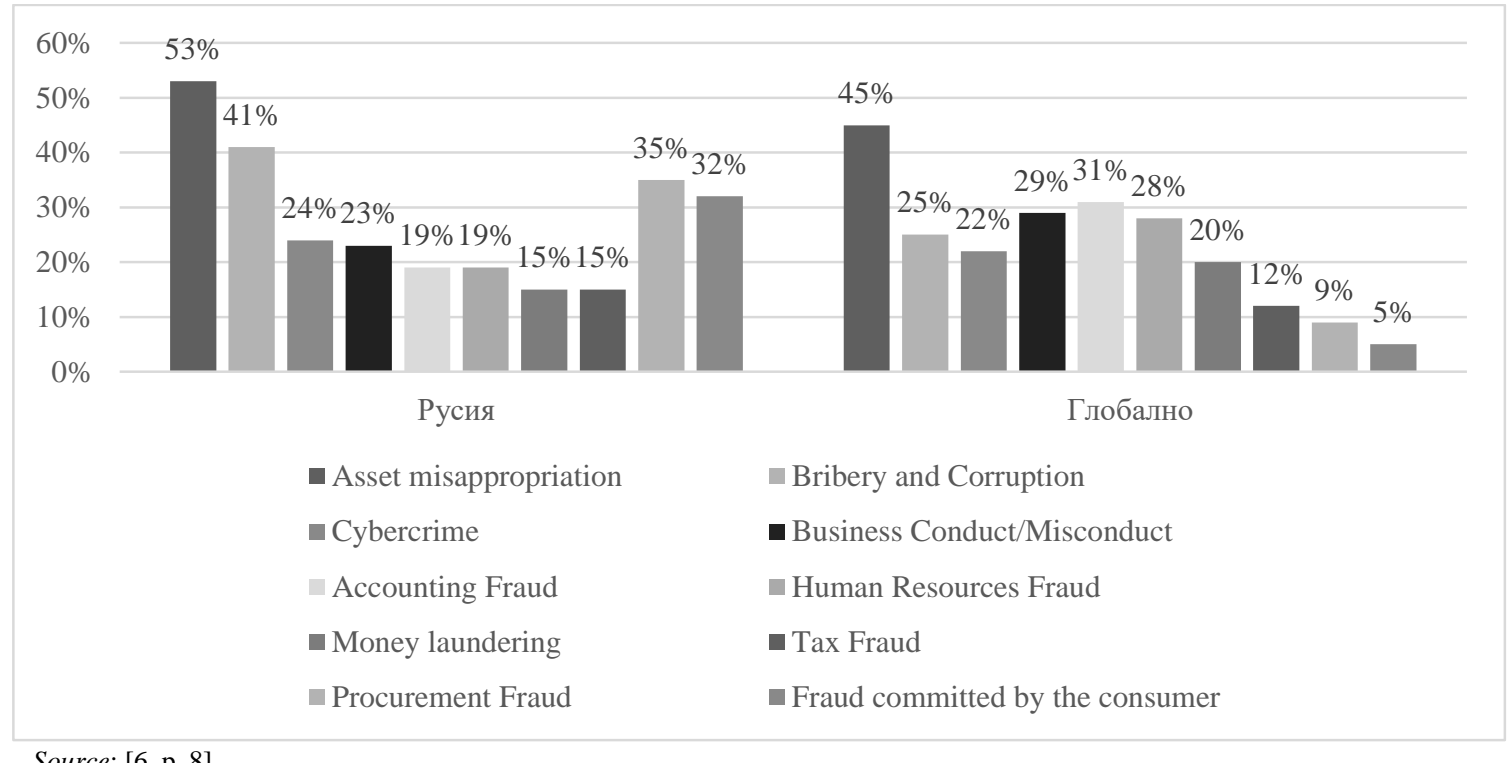

Figure 2. Economic crime in Russia and worldwide (2018)

The figure above shows the relative shares of reported cases of various types of an economic crime - asset misappropriation (53\%), corruption and bribery (41\%) and procurement and supply fraud (35\%). The difference between the levels in Russia and the worldwide average levels is indicative of the criminal environment in Russia, which is probably due to the high level of corruption and bribery, which ranks second in the Russian Federation. The levels of tax fraud (15\%) and money laundering (15\%) are lowest. The same difference holds through in comparison to Bulgaria as well:

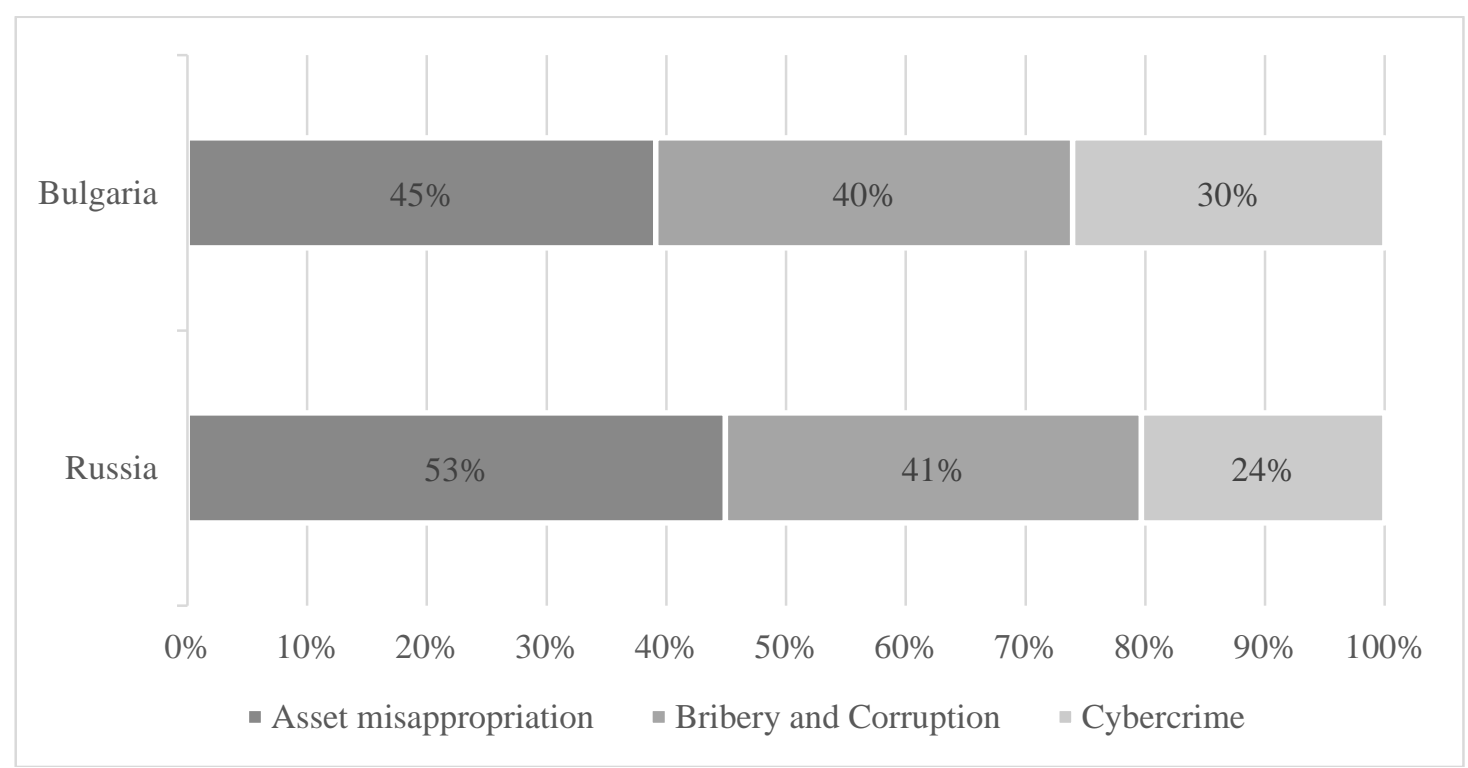

Figure 3. Top ranking types of economic crime in Bulgaria and Russia (adapted from [5-6])

The three most common types of an economic crime reported in Bulgaria are asset misappropriation (45 \%), corruption and bribery $(40 \%)$ and cybercrime (30\%). Especially interesting is the fact that the share of cybercrime (deemed the new global threat) reported in the Russian Federation is lower. Nonetheless, according to Interpol 
data for 2017, the main type of a cybercrime in many countries is ransomware. ${ }^{1}$ Examples of such malware are the WannaCry and NotPetya applications, which affected about 300,000 people (globally) and resulted in losses amounting to \$4 billion. Another malware application, Bad Rabbit, affected about 200 users mostly from Russia and Eastern Europe. Its main targets are critical areas such as healthcare, transportation, and the financial sector. [7, p. 16]. This fact shows that cybercrime prevention authorities of the surveyed countries are efficient. The smaller number of cybercrime cases may be due to regulatory compliance, highly specialized and competent authorities, as well as awareness of crime trends (not only in Russia but worldwide).

The number of crimes against property and economic crimes reported in Russia in the period of January-July 2019 is shown in Table 1 below:

Number of economic crimes reported in the period of January - July 2019

\begin{tabular}{|c|c|c|}
\hline Type of crime & $\begin{array}{c}\text { Cases } \\
\text { (no.) }\end{array}$ & $\begin{array}{c}\text { Grave and especiall grave crimes } \\
\text { (no.) }\end{array}$ \\
\hline Theft & 687 & 159 \\
\hline Fraud & 18876 & 11031 \\
\hline Embezzlement & 4400 & 6 \\
\hline $\begin{array}{c}\text { Making, custody, carriage or sale of counterfeit } \\
\text { banknotes or securities }\end{array}$ & 11324 & 278 \\
\hline $\begin{array}{c}\text { Laundering of funds and other property acquired } \\
\text { illegaly }\end{array}$ & 618 & 36 \\
\hline $\begin{array}{c}\text { Illegal turnover of precious metals, natural precious } \\
\text { stones and pearls }\end{array}$ & 40 & 3678 \\
\hline
\end{tabular}

Source: $[8$, p. 37]

According to the table, fraud is the most numerous type of crime accounting for 18876 cases, of which 11031 were grave or especially grave, i.e. crimes that affect to a significant degree the integrity and property of individuals, the society or the state. The fewest is the number of reported cases of illegal turnover of precious metals, natural precious stones and pearls (40), almost all of which were grave or especially grave - 36 pcs. Another disconcerting fact is the number of crimes related to making, custody, carriage or sale of counterfeit banknotes or securities (11324), but unlike the others, the number of grave and especially grave cases in this category is very small -6 .

In addition to the number of economic crimes reported, we should also take into account the way they are detected. The main methods of detection are internal auditing, fraud risk assessment, suspicious activity monitoring, corporate security, data analytics, and staff rotation. The relative share of crimes detected using each of these methods is shown in the figure below.

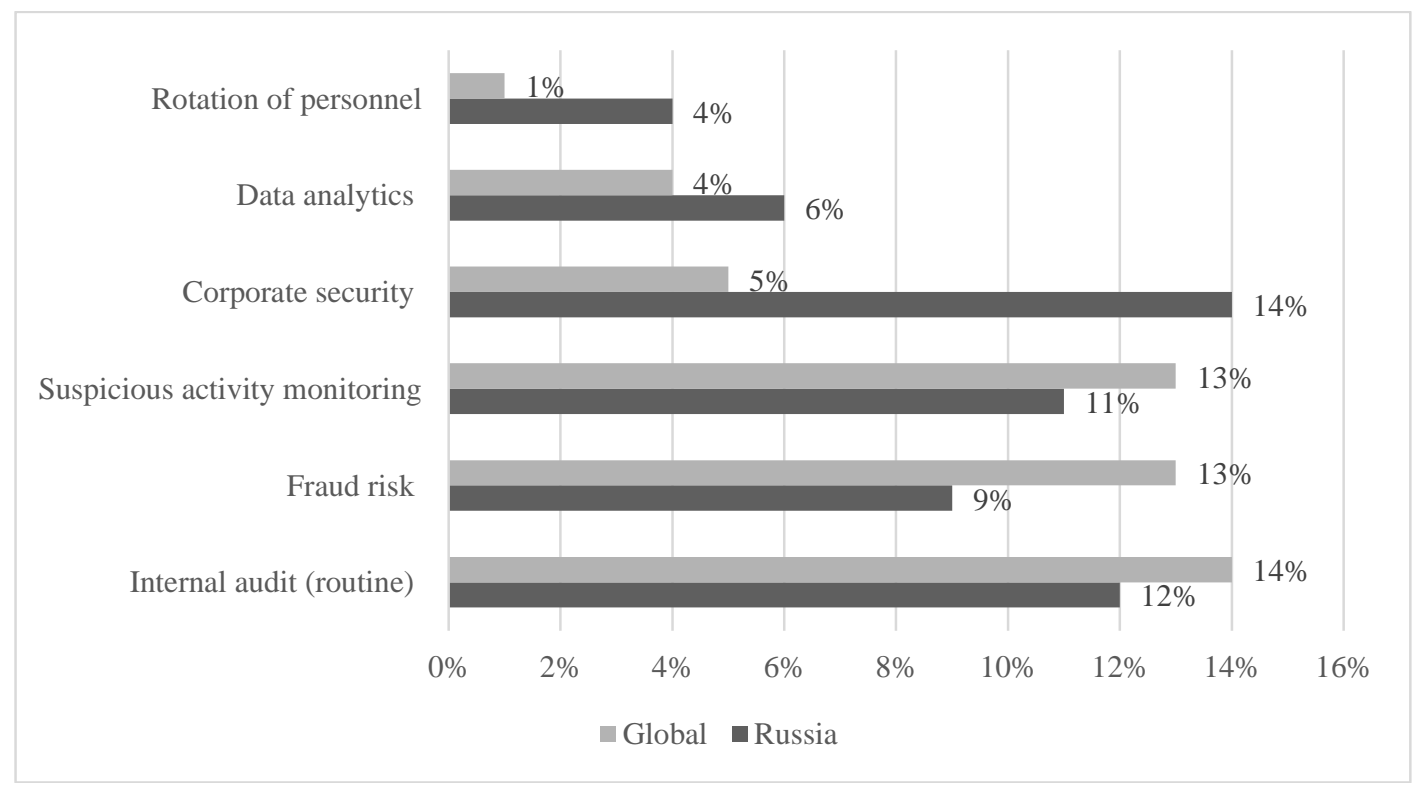

Source: $[6$, p. 11]

Figure 4. Crime detection methods (Russia)

\footnotetext{
${ }^{1}$ Note: ransomware is a type of malware that prevent or restricts the users' access to their systems or devices requiring them to pay ransom through certain payment methods (and within a certain timeframe) in order to regain control over their data [12]
} 
The methods that are used most widely for detection of economic crimes in Russia, as shown in the figure, are corporate controls (security) - $14 \%$ and internal audit $-12 \%$. This means that the organizations in this country rely on their own resources, whether human or logistical, rather than on external organizations and professionals. This is confirmed by the lowest percentage (4\%) of crimes detected using staff rotation. According to PwC's 2018 Global Economic Crime and Fraud Survey, $74 \%$ of the respondents in Bulgaria stated that they have implemented technological solutions against fraud and/or other economic crimes. Seventy-two percent support the idea of using real-time monitoring. Technologies allow the implementation of effective and proactive measures against this type of crime and its negative effects. [5, p. 14]. However, the survey showed that in 2009 crime detection and prevention relied on different types of controls:

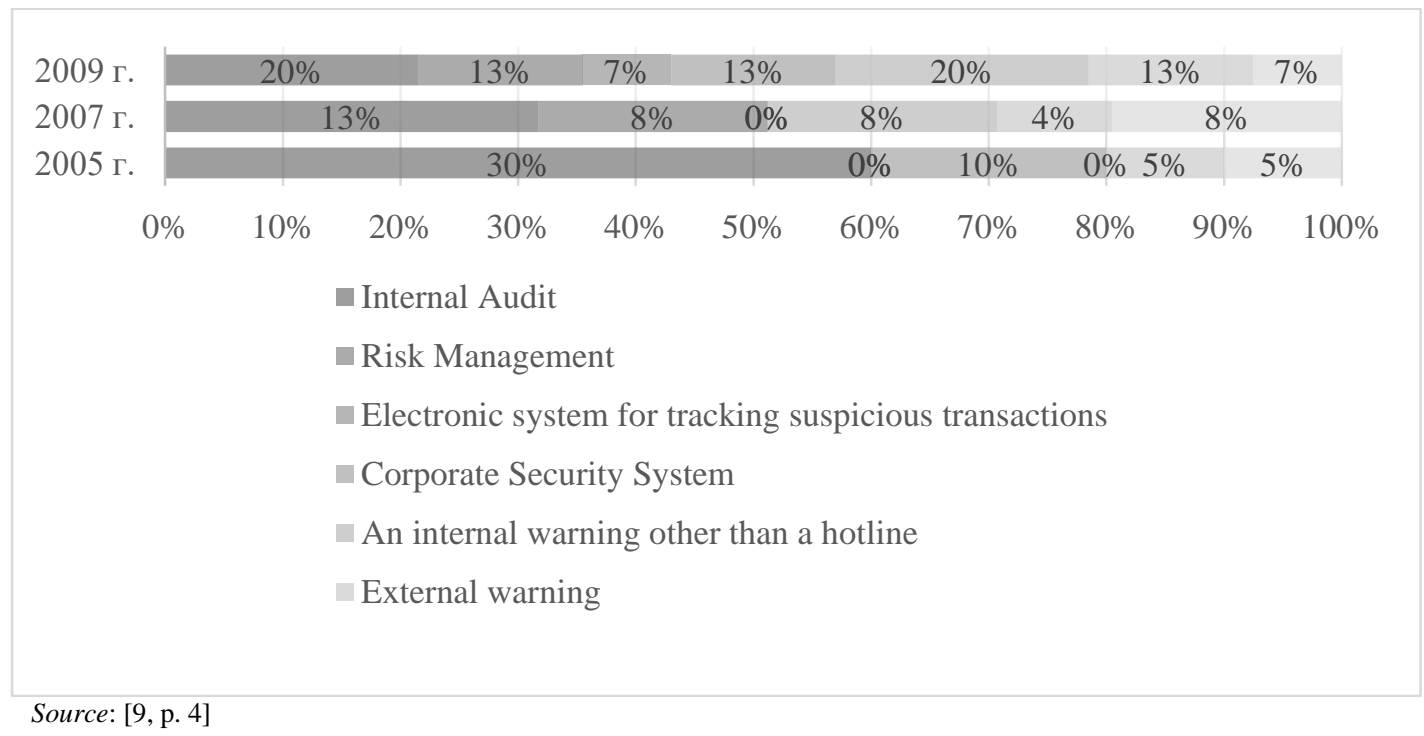

\section{Figure 5. Crime detection methods (Bulgaria)}

In 2009, internal audit $(20 \%)$ and internal warning systems other than the hotlines $(20 \%)$ were the most widely used methods for crime detection. The least frequently used methods were the internal informant/hotline (7\%) and the electronic system for tracking suspicious transactions (7\%). This indicates that crime detection relied mainly on internal controls, which were not appropriate or effective enough and were gradually abandoned. In the years before 2009, electronic systems were not used at all. This is indicative of the gradual development of the capacity and skills of the control bodies to detect economic crime using new and adequate methods and tools. In order to be efficient in detection and prevention of economic crimes, companies must establish and maintain corporate culture with clear ethical rules and standards of conduct at all hierarchical levels, thereby mitigating their business risks. Regardless of the ways (methods) for detection of economic crimes, the main objective of all businesses and government bodies is to minimize the losses incurred from such crimes.

Loss assessment is a process which includes not only assessment of tangible damage and financial losses, but also psychological and reputational damage (demotivation of staff, deterioration of relationships with customers and partners, etc.). The PwC's surveys show that the largest number of cases in Bulgaria result in losses amounting between USD 100,000 and 1 million (35\%). The fact that $25 \%$ of the respondents answered «I don't know», i.e. that they had no idea what the losses were, either in material or reputational aspect is rather worrying. [5, p. 11] In 2016, the largest percentage (31\%) of losses were below $\$ 50,000$. The same percentage was reported for losses between $\$ 100,000$ and \$ 1 million. The smallest is the percentage of losses between $\$ 1$ million and \$ 5 million. [10, p. 13] At the same time, in 2018 the prevailing amount of losses incurred in Russia is less than $\$ 100$ thousand (41\%). In 2016 , the greatest relative share was that of losses below $\$ 50,000$ (36\%), i.e. the country managed to maintain a moderate level of fraud losses. Compared to 2018, the amount of loss is lower and remain below that level. The number of cases with losses between $\$ 5$ million and \$100 million was the smallest in 2016 (4 \%). [11, p. 9].

Results and Conclusion. The results from the analysis of economic crime dynamics lead to the following conclusions:

First. The definitions of crime in Russia and Bulgaria differ mainly in terms of the characteristics which define an act as a crime, which are four in Bulgaria's Criminal Code (culpability, illegality, social danger, and penal liability) and five in Russia's Criminal Code (the additional feature refers to psychological acts). Another thing that distinguishes Russia's criminal law from that of Bulgaria is the categorization of the types of economic crime.

Second. The level of economic crimes in the Russian Federation is higher than that in Bulgaria and worldwide. The main types of such crimes are asset misappropriation, corruption and bribery related to public procurement and supplies while in Bulgaria these are in the same stead with cybercrime. The high crime levels indicate ineffectiveness of the methods used for prevention and detection. Combatting economic crime is a continuous 
process that involves the continuous improvement of the competences, knowledge and skills of both the authorities responsible for dealing with economic crime and the management of the organizations.

Third. The methods used for detection of economic crime are clearly ineffective. Bulgaria relies mainly on real-time monitoring and high-tech solutions, while Russia relies on data analysis, risk assessment, internal audit, with corporate controls (security) and internal audit are the most commonly used methods. Nonetheless, surveys indicate that the levels of economic crime keep rising.

Fourth. The amount of loss per case of economic crime also differs across the two countries. The average loss of Bulgaria is between $\$ 100,000$ and \$ 1 million, while in the Russian Federation the larger share accounts for losses of up to $\$ 100,000$. This fact contradicts the economic crime data reported by Russia. On the one hand, the number of crimes is far greater than that in Bulgaria and worldwide, and on the other hand, these crimes result in less damage.

These conclusions show that economic crime is a serious problem area for both Bulgaria and Russia. Although the methods, tools and approaches used to combat them are constantly improving and modernizing, the number of crimes is still going up (especially in Russia). Since an economic crime is complex and dynamic, its detection and prevention is an ongoing, holistic process that must be backed up with the right methods and tools.

\section{Список використаної літератури:}

1. Кримінальний кодекс Болгарії: зміни та доповнення // Державний вісник. - 2019. - № 16.

2. Филчев Н. Лекції з кримінального права / Н.Филчев. - Софія : Схід-Захід, 2014.

3. Уголовный кодекс Российской Федерации : ред. 2019 / Уголовный кодекс РФ от 13 июня 1996 г. № 63-Ф3 // Собрание законодательства Российской Федерации. - 17 июня 1996 г. - № 25.

4. Уголовное право России. Особенная частъ / С.Балеев, А.Кузнецов, Л.Кругликов и др. - М. : Статут, 2012.

5. Сандбі П.А. Звіт про глобальне обстеження економічної злочинності 2018 року для Болгарії. Що залишилося в тіні? / П.А. Сандбі, Р.Мамасян // РwC. - 2018.

6. Мюллер $P$. Боротьба 3 шахрайством: заходи, вжиті компаніями. Російське обстеження економічної злочинності та шахрайства 2018 / Р.Мюллер // РwC. - 2018.

7. Оцінка загрози Інтернет-організованої злочинності / Агентство Свропейського Союзу 3 питань правоохоронного співробітництва // Європол. - 2018.

8. Состояние преступности в России / Министерство внутренних дел Российской Федерации : ФКУ «Главный информационно-аналитический центр». - Москва. - январь-июль, 2019.

9. Нейчев Б. Економічна злочинність у фінансовій кризі. Глобальне опитування злочинності бізнесу / Б.Нейчев, А.Маркова, К.Озмен // РwC. - 2009.

10. Сандбі П.А. Глобальне опитування злочинності в бізнесі 2016 року - результати для Болгарії. Готові захистити себе? (Ваші конкуренти!) / П.А. Сандбі, А.Маркова, Р.Мамасян // РwC. - 2016.

11. Дивлячись у майбутнє з обережним оптимізмом. Обстеження економічної злочинності в Росії / I.N. Novikova, I.Fokina, T.Vostrova, A.Ulyakin // PwC. - 2016.

12. Wanna Cry Ransomware // Свропол. - 2017.

\section{References:}

1. «Kryminal'nyj kodeks Bolgarii': zminy ta dopovnennja» (2019), Derzhavnyj visnyk, No. 16.

2. Fylchev, N. (2014), Lekcii' z kryminal'nogo prava, Shid-Zahid, Sofija.

3. «Ugolonnyj kodeks Rossijskoj Federacii» (2019), v redakcii, ot 13 ijunja 1996 g., No. 63-FZ, Sobranie zakonodatel'stva Rossijskoj Federacii, ot 17 ijunja 1996 g., No. 25.

4. Baleev, S., Kuznecov, A., Kruglikov, L., and other (2012), Ugolovnoe pravo Rossii. Osobennaja chast, Statut, Moskva.

5. Sundby, P.A. and Mamasjan, R. (2018), «Zvit pro global'ne obstezhennja ekonomichnoi' zlochynnosti 2018 roku dlja Bolgarii'. Shho zalyshylosja v tini?», $P w C$.

6. Muller, R. (2018), «Borot'ba z shahrajstvom: zahody, v zhyti kompanijamy. Rosijs'ke obstezhennja ekonomichnoi' zlochynnosti ta shahrajstva 2018», $P w C$.

7. Agentstvo Jevropejs'kogo Sojuzu z pytan' pravoohoronnogo spivrobitnyctva (2018), «Ocinka zagrozy Internetorganizovanoi' zlochynnosti», Jevropol.

8. Ministerstvo vnutrennih del Rossijskoj Federacii (2019), Sostojanie prestupnosti v Rossii, FKU «Glavnyj informacionno-analiticheskij centr», from janvar'-ijul', Moskva.

9. Nejchev, B., Markova, A. and Ozmen, K. (2009), «Ekonomichna zlochynnist' u finansovij kryzi. Global'ne opytuvannja zlochynnosti biznesu», $P w C$.

10. Sundby, P.A., Markova, A. and Mamasjan, R. (2016), «Global'ne opytuvannja zlochynnosti v biznesi 2016 roku rezul'taty dlja Bolgarii'. Gotovi zahystyty sebe? (Vashi konkurenty!)», $P w C$.

11. Novikova, I.N., Fokina, I., Vostrova, T. and Ulyakin, A. (2016), «Dyvljachys' u majbutnje z oberezhnym optymizmom. Obstezhennja ekonomichnoi' zlochynnosti v Rosii'», $P w C$.

12. «Wanna Cry Ransomware» (2017), Jevropol.

Василев Пресіян Ільянов - PhD-студент кафедри управління та аналізу господарської діяльності Економічної академії ім. Д.А. Ценова, Свіштов, Республіка Болгарія.

Наукові інтереси:

- фінансовий аудит; запобігання та виявлення шахрайства; фінансовий контроль; кіберзлочинність; кримінологія. 